\title{
A Recreational Valuation of the Freshwater Inflows into the Keurbooms Estuary by means of a Contingent Valuation Study ${ }^{1}$
}

SG Hosking and M du Preez

Department of Economics and Economic History, University of Port Elizabeth

\section{ABSTRACT}

This paper reports on a contingent valuation made of the freshwater inflow into the Keurbooms Estuary near Plettenberg Bay, South Africa, in April 2001. The value of this water was estimated in terms of the services yielded to recreation users of the estuary, to be between $\mathrm{R} 0,012 / \mathrm{m}^{3}$ and $\mathrm{R} 0,046 / \mathrm{m}^{3}$. This value is currently lower than what farmers are willing to pay for the water in this area, as measured by the income capitalisation method, namely $\mathrm{R} 0,125 / \mathrm{m}^{3}$, but may increase in the future as more and more South African estuaries are undermined through upstream river water abstraction, and recreational substitutes are diminished. A willingness-topay function was also estimated and show annual levies paid and investment in goods to access the estuary services to be important determinants of willingness-topay.

JEL Q25, 26

\section{INTRODUCTION}

The water of the Keurbooms River near the Southern Cape town of Plettenberg Bay, South Africa, is demanded both for use in the town and in the estuary, where its inflow is needed to preserve environmental services used for recreation. The estuary (Fig. 1) derives its freshwater supplies through inflows from the Keurbooms and Bitou rivers (Hosking et al., 2002). These inflows are determined by many factors; two important management ones being discretionary dam water releases and the actions of the Working for Water Programme (an alien vegetation clearing programme) in the upper reaches of the catchments of these rivers. At the current rate of freshwater inflows the estuary mouth is kept open, but it is alleged by scientific reports on estuaries along this part of the South African coast (Wooldridge, 2000) that decreases of freshwater inflows below this rate would cause the mouth to choke with sediment leading to a reduced tidal prism - water flows in and out of the mouth. Reduced freshwater inflows and the sand movement around the mouth, created by waves and longshore drift, can lead to complete 
mouth closure within days. Mouth closure tends to occur for long periods of time (i.e. for the bulk of the year).

For the duration of the closure of the estuary mouth the following negative ecological impacts would occur:

- the disappearance of foraging birds in the intertidal areas;

- $\quad$ a reduction in the total area available for boating around the mouth of the estuary (below the bridge on the N2) due to a drop in water level and shallowing of the lower estuary;

- a reduction in availability of mudprawn, which is the major bait organism for fishers, of 25 per cent per annum, with a total loss after 4 years of the 70 million mudprawn currently available;

- $\quad$ a reduction in estuary fish availability (for example, spotted grunter and dusky cob) for recreational angling because no regeneration would take place;

- the total loss of migratory fish in the estuary (those that move between the estuary and the ocean), such as garrick (leervis) and shad (elf), for recreational fishing;

- a reduction in water frontage space along the banks of the estuary and exposure of large expanses of sand and mud;

- $\quad$ an increase in decaying aquatic vegetation (weedbeds) due to exposure;

- a total loss of fishing habitat in the mouth channel of the estuary for shore based and/or boat fishing; and

- a total loss of marine fish species that use the estuary as a nursery area (Bennet, 1989; Blaber \& Whitfield, 1976; Huizinga \& Slinger, 1996; Reddering, 1988; Whitfield, 1989; Whitfield \& Kok, 1992; Wooldridge, 2000).

As a result of these negative ecological impacts, negative economic impacts occur. Wooldridge (2000) maintains that the degree of confidence regarding the occurrence of the ecological impacts upon mouth closure is 100 per cent. These negative ecological impacts also have negative economic consequences. The residential and holiday recreational attractiveness of the Plettenberg Bay area would be reduced, and this is the point on which this paper sought to make a contribution.

The contribution is in the form of deriving a measure of this reduction in recreational value in Rand using the contingent valuation method $(\mathrm{CVM})^{2}$. The CVM was applied by administering willingness-to-pay questionnaires to 150 selected respondents in the area during April 2001. This number contributed about 5 per cent of the sample population. Given the smallness of the sample size the 
potential for error exists in the results. The respondents were asked what they were prepared to pay for a project that would maintain the freshwater inflows at their current level so as to prevent the negative ecological impacts (listed above) consequent upon closure of the Keurbooms Estuary mouth.

\section{APPLYING THE THEORY OF CVM TO THE KEURBOOMS}

As a consequence of reduced freshwater inflows into the Keurbooms Estuary and increasing consumption demand for water in the Plettenberg Bay area, at some point (in the near future) the mouth of the Keurbooms Estuary will close. When this happens a whole range of environmental services on which recreation is dependent will be negatively affected (as listed above).

The hypothesis of this study is that the people who use these services are prepared to pay to prevent these negative impacts from occurring, or would be prepared to accept compensation if it did occur, which would leave them as well off as they were before the closure.

\section{Figure 1 The Keurbooms and Bitou estuaries}

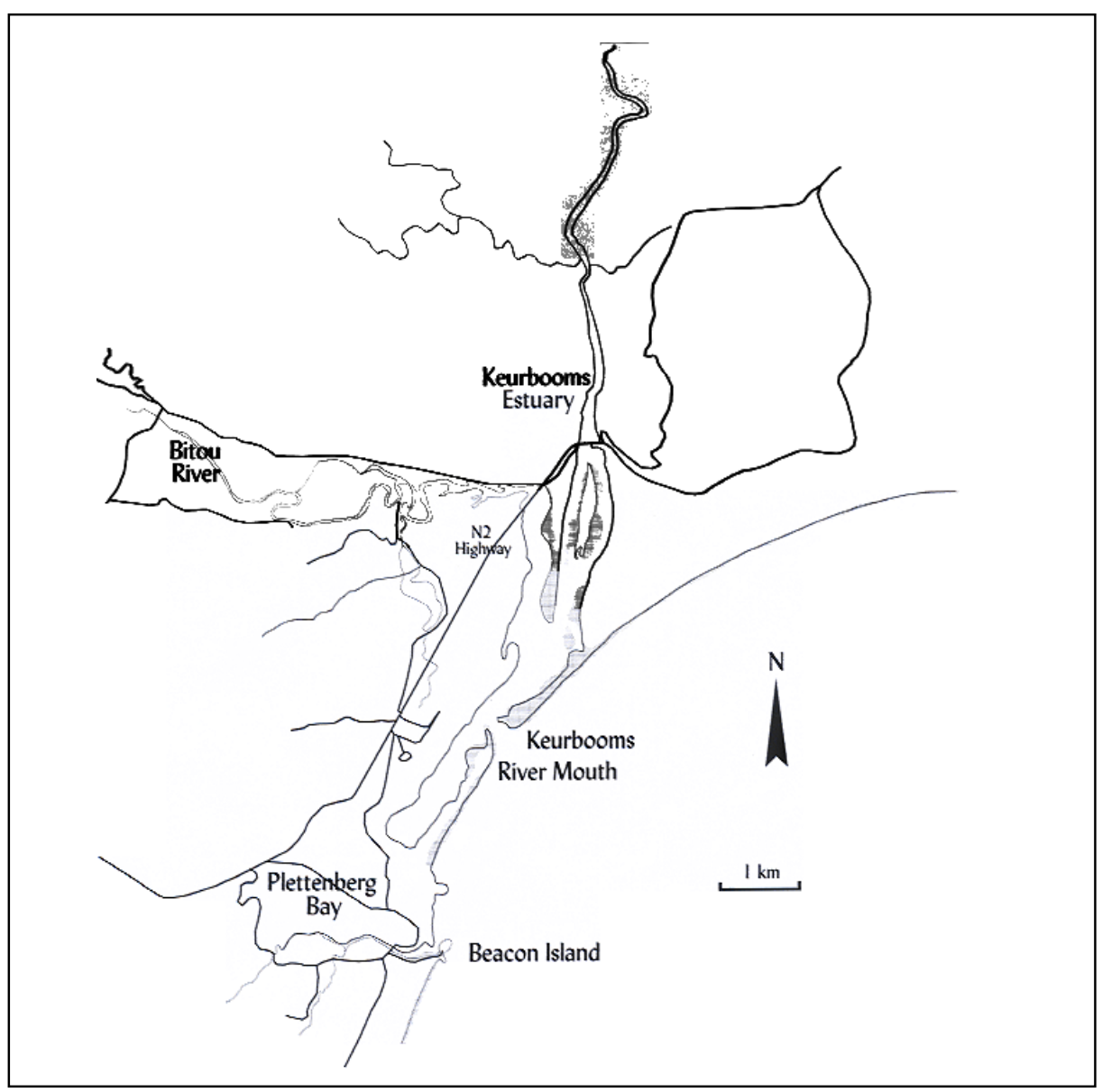


These people include those people who currently use the Keurbooms Estuary, those people who value it for their children, those people who value it simply as an option for them to use in the future, and those people who value it simply because it is there. Respondents were asked to value the increment of freshwater flowing into the estuary in terms of the recreational value it yields in the estuary. If this water was instead abstracted from the river it could be used for consumptive purposes in the town of Plettenberg Bay.

The value of these services can be determined from responses of the affected people to questions of what they were willing to pay to prevent the loss of these services or what they would be willing to accept to compensate them for the loss (Hanemann, 1999). These questions usually elicit responses of different magnitudes with stated willingness-to-accept typically exceeding actual willingness-to-pay. This paper applied the more conservative willingness-to-pay approach, and deemed the average willingness-to-pay to be the price of the river freshwater inflows into the Keurbooms Estuary.

\section{RESEARCH DESIGN}

Contingent valuation method is a survey technique that is used to place monetary values on products and services for which market prices do not exist or do not reflect the real value of the good/service (Tietenberg, 2000). Respondents are presented with hypothetical scenarios and asked questions about the amount of money they would be prepared to spend to make them become reality. The values that are derived are "contingent" upon the realisation of the scenarios (Hanley and Spash, 1993). Ciriacy-Wantrup (1952) was one of the first proponents of CVM. Davis (1963) used CVM to derive the recreational value of woodlands in the United States of America. It has been refined both theoretically and empirically during the 1970s, 1980s, and even in the 1990s, mainly in the United States of America, where it has been most frequently employed to generate values for environmental amenities (e.g. sport fishing) and public goods (e.g. national parks). Some skepticism has been expressed regarding the usefulness of CVM in a developing country context (Dixon \& Sherman, 1990). According to Whittington (1996) it was believed a decade ago that CVM could not be carried out in developing countries for reasons related to the overwhelming problems experienced in soliciting answers to hypothetical questions from low-income and possibly illiterate respondents. A number of studies have, however, shown that meaningful CVM studies can be applied to developing countries (Georgiou et al., 1997; Whittington, 1996). Most of the CVM studies conducted in developing countries focus on issues related to water quality improvements and sanitation (see for example, Aguilar \& Sterner, 1995; Griffin et al., 1995; Whittington et al., 
1990). In South Africa this method is being increasingly applied, even in the field of water pricing (see for example, Veck \& Bill, 2000; Turpie \& Joubert, 2000).

\subsection{Population and sample}

The first step taken in this contingent valuation of the Keurbooms Estuary was to determine the sampling frame and select a representative sample from it.

The first problem that was encountered in this connection was who to include in the sample frame as non-current-users, i.e. people who value the estuary for bequest, option or existence reasons. We were unable to identify this population and so omitted this category of demanders of the estuary services. For this reason the sample frame was deemed to consist only of users ${ }^{3}$ of the Keurbooms Estuary in the Plettenberg Bay area during the year 2001. These people were determined through consultation with local authorities and the conducting of pilot studies on the users of the estuary. The following institutions were used to identify the sample frame: the angling club, the bird-watching club, town planning department, hotels, camp sites and owners of Bed and Breakfast establishments, and the Department of Nature Conservation. Following these consultations it was deduced that the total sample population was 13250 people per annum (of residents and visitors). From these authorities it was further deduced that this sample could be roughly divided into the following sub-groups: anglers (1 800), baiters (600), swimmers (5 400), water frontage/access (490), birdwatchers (60), boaters (1 400) and scenic benefit ( 3500$)$. Most of these users were multiple users but they were allocated on the basis of what their main use was expected to be. For instance, most of the 600 baiters were also anglers, but because they spent more time collecting bait than fishing they were stratified as baiters. Assuming average size households of four people the total sample size translates into about 3312 households.

The average number of anglers and bait collectors using the Keurbooms Estuary per annum was estimated from information supplied by the nature conservation authority on the number of licenses issued per annum. Angling and bait collecting is subject to strict control measures. The average number of swimmers and boaters making use of the estuary per annum was also obtained from the nature conservation authority who strictly control access to the estuary. Boaters require a license to use the estuary. The number of birdwatchers using the Keurbooms Estuary per annum was determined by reference to the birdwatchers registered with the bird-watching club in Plettenberg Bay. The number of people owning water frontage space with direct access to the estuary was determined in consultation with the town planning department of Plettenberg Bay. The number of people deriving a scenic benefit per annum from the estuary was determined by estimating 
the proportion of the town's population which enjoyed direct view benefits. This analysis was also done in conjunction with the town planning department.

In order to select a sample of people to be interviewed from this sample frame a stratified sampling technique was used. Five strata of users were utilised, namely, fishermen, boaters, swimmers/bathers, water frontage owners and others (for example bird-watchers). Proportionate sampling was used whereby the size of the sample drawn for each stratum was proportionate to the relative size of that stratum in the total population. The proportional allocation formula was as follows:

$$
\mathrm{n}_{\hbar}=\frac{\mathrm{nN}_{\hbar}}{\mathrm{N}}
$$

where: $\mathrm{n}_{n}=$ sample size for stratum $\hbar$

$$
\begin{array}{lll}
\mathrm{n} & = & \text { size of total sample drawn } \\
\mathrm{N}_{n} & = & \text { size of stratum population } \\
\mathrm{N} & = & \text { size of total sample population. }
\end{array}
$$

Proportional allocation assumes that the strata are independent.

In total 150 people out of the sample frame of 13250 were interviewed (about 1 per cent). A cost efficient sampling design is a crucial step in applying the CVM. There are various aspects to consider in this connection. The sample should be randomly selected and administered at a time which reduces the potential for biases. Moreover, the size of the sample selected should be as great as the research budget allows (Choe et al., 1999). The above objectives were pursued in the following ways. April 2001 was selected in order to obtain a mix of vacation and permanent resident users, respondents were randomly approached and the budget allowed 150 people to be surveyed (a 5 per cent sample size). Personal interviews are expensive and time-consuming, but they do allow for more complicated scenarios to be explained and this was indeed needed. Conveying information over the telephone is difficult due to time constraints, but it is relatively inexpensive. Mail surveys tend to suffer from a non-response bias and low response rates, but these surveys do have the advantage that they avoid interviewer bias (Mitchell and Carson, 1989).

\subsection{The Questionnaire}

(i) The willingness-to-pay question

The main purpose of the questionnaire was to ask users of the Keurbooms Estuary what they were willing to pay for a project that would maintain the freshwater inflows into the Keurbooms Estuary at their current levels. The maintenance of 
freshwater inflows wouldprevent closure of the Keurbooms mouth. In turn this would prevent the negative ecological (see as described earlier) and recreation function impacts from occurring. This question corresponded to a potential future event (mouth closure) and not one that had already occurred. The willingness-topay amounts were elicited by means of a payment card approach whereby respondents were asked to circle the value that represents their maximum willingness-to-pay for the project in question, given a range of numbers listed on the survey form. The listed range of numbers were chosen in accordance with the typical expenditure by respondents on other publicly provided services as suggested by Hanley and Spash (1993). This elicitation mechanism is preferred because it is not subject to starting-point biases (Hanley \& Spash, 1993).

An important part of the willingness-to-pay approach is the bid or payment vehicle (how the funds to make the payment were raised). The respondents were informed that this would take the form of a levy collected from all users who derive benefit directly or indirectly, e.g. by providing visitors access to the Keurbooms Estuary.

An important bias that can occur when applying the willingness-to-pay approach is the mental account bias, that is mental error in calculating what the person would be willing to pay (Hanley \& Spash, 1993). In order to reduce it, respondents were reminded by the enumerator of their budget constraints - that spending for this good/service necessarily meant a reduction in other kinds of goods/services that could be purchased. They were asked what they would sacrifice in order to make this payment.

In a further attempt to reduce mental account bias, respondents were also made aware of possible substitutes for the good/service that they were valuing. The intention of the substitutes question was to sensitise the respondents to the fact that there were alternatives to the Keurbooms Estuary in the area and they should take this into account when deciding what they are willing to pay. The respondents were asked how they would go about satisfying their demand for the services provided by the Keurbooms Estuary if the Keurbooms mouth were to close and if they were to lose the availability of its services. The alternatives cited were the Wilderness, Knysna Lagoon, Jeffreys Bay and St Francis Bay.

An important component of a contingent valuation survey is the respondents' knowledge about the service they are valuing. The respondents' prior knowledge of the ecological function of the Keurbooms Estuary was tested by asking them what they thought would happen if no fresh water was allowed to flow into the Keurbooms Estuary and the mouth closed. To assist the enumerator the following list of impacts was provided: 
- A significant shrinkage in the total area of estuary available for boating and other activities;

- $\quad$ A reduction/total loss of bait for fishermen, especially prawn;

- A reduction in fish available to be caught in the estuary and off shore, including estuary fish species (like spotted grunter and dusky cob) and migratory species (like garrick and shad);

- An increase in smelly decaying aquatic vegetation (exposed due to lower water levels);

- A total loss of foraging birds in the intertidal area around the estuary;

- A less attractive estuary and mouth shoreline (mud flats where water receded); and

- Increased potential for flooding of low lying properties near the Keurbooms when dams on this river overflow (because of sand bar build up at the mouth making a natural dam wall).

A respondent was judged to be well-informed if he/she was aware of three or more of the listed possible impacts, and poorly-informed if aware of less than three. The numerator explained those impacts of which the respondents were not aware. In addition to the above information the following was also conveyed to the respondents:

- The benefits of maintaining the freshwater inflow into the Keurbooms Estuary, either through the Working for Water Programme or dam water releases, would be available to all people who reside in Plettenberg Bay, or otherwise benefit from activities within the Keurbooms Estuary.

- Users of this water (residents and tourists) would be expected to make contributions towards catchment management or dam water releases. The managing authority would be the Plettenberg Bay Municipality.

- $\quad$ The respondents would be paying for water generated through the Working for Water Programme as natural runoff, to be released from dams in sufficient quantity to keep the mouth of the Keurbooms Estuary open.

(ii) The factors expected to affect willingness to pay questions

- Annual levies

Those people paying more in levies are revealing a higher willingness-topay than those paying less. Accordingly it was expected that people who were paying more already would also respond that they were willing to pay more in the hypothetical case described than those who were currently paying less.

- $\quad$ Gender of the respondent

We were not sure what role gender would play, if any, but were interested to see if it did. 
- Location

People living in close proximity to the Keurbooms Estuary were expected to be more disposed to making contributions than people living further away.

- Worth of owned fixed property

People with greater wealth were expected to be more disposed to/capable of making contributions than people who own properties of lesser worth.

- Worth of vehicles and boats

People with greater investment in access assets (to get to and use the estuary services) were expected to be more disposed to/capable of making contributions than people with lower investment in this type of asset.

- $\quad$ Education level of respondent

People with more education were expected to be more aware of and sensitive to the ecological benefits for the estuary of freshwater inflows and therefore willing to pay more for them.

- Gross annual income of respondent

People with higher gross annual incomes were expected to be capable of paying more than lower income earners simply because their budgets allowed for this.

The questionnaire was pre-tested by a team of four interviewers in a pilot study. Following this survey the questionnaire was simplified and some technical terms were replaced by those used in everyday language.

One enumerator administered the questionnaire to all 150 users selected to be interviewed during April 2001.

\section{EMPIRICAL ANALYSIS AND DISCUSSION}

\subsection{Invalid responses}

An important starting step in analysing responses to CVM questionnaires is to check them for validity. The two main types of responses sometimes deemed invalid and excluded are protest zeros and outliers. Protest zero bids are bids provided by respondents for reasons other than a zero value being placed on the environmental good or service which is being valued. Outliers, on the other hand, are simply very large bids.

The approach used most often to deal with invalid responses is to discard these observations (protest zeros and outliers), but this is incorrect from a statistical point of view (Carson, 1991). Protest zeros are usually determined by reference to the question why individuals were not willing to pay, where they said they were not 
prepared to pay anything. Outliers are determined by the researcher on the number of standard deviations the response is away from the mean WTP.

Out of 150 responses, 25 (or 17 per cent) gave what we deemed to be invalid responses to the valuation question. As is usually the case for in-person interviews, the item non-response was zero. Responses stating that the Plettenberg Bay Municipality should pay for everything were deemed by us to be protest responses. They made up about 92 per cent of the invalid responses ( 23 responses). Outliers made up 8 per cent of invalid responses ( 2 responses). These were defined to be those willing to pay (WTP) responses that were more than 3 standard deviations above the mean willingness-to-pay.

A comparison of means of variables for respondents with invalid and valid responses to the valuation question was carried out to test for differences between the two groups. The results are shown in Table 1.

Table 1 Comparison of means of variables for respondents with invalid and valid responses to the valuation question

\begin{tabular}{|l|c|c|c|}
\hline Variable & $\begin{array}{c}\text { Mean for valid } \\
\text { responses }\end{array}$ & $\begin{array}{c}\text { Mean for } \\
\text { invalid } \\
\text { responses }\end{array}$ & t-statistic \\
\hline Annual levies & 205.67 & 174.50 & -0.73 \\
Distance & 5.70 & 3.95 & -1.58 \\
Worth - fixed property & 798330 & 673330 & -1.24 \\
Worth - boats/vehicles & 134380 & 113330 & -0.64 \\
Income & 168210 & 147000 & -1.20 \\
\hline Number of observations & 120 & 30 & \\
\hline
\end{tabular}

Table 2 The Pearson Chi-Square test for independence

\begin{tabular}{|l|l|}
\hline Variable & Independence hypothesis \\
\hline Information & Rejected at 95\% C.L. \\
Annual levies & Not rejected \\
Freshwater worth & Rejected at 99\% C.L. \\
Gender & Not rejected \\
Distance & Not rejected \\
Education & Rejected at 95\% C.L. \\
Worth - fixed property & Rejected at 95\% C.L. \\
Worth - boats/vehicles & Not rejected \\
Income & Not rejected \\
\hline \hline
\end{tabular}


The fact that the null hypothesis holds in the comparison of means tests suggests that there were no significant differences in terms of characteristics between those who gave valid and invalid responses. However, the Pearson Chi-Square test for independence yielded different results. This test's results are shown in Table 2.

Four of the nine variables listed in Table 2 (stating independence) were rejected in terms of the null hypotheses. In view of the results of this test it was deduced that the valid and invalid responses represented different types of respondent, and that in order to avoid the occurrence of sample selection bias, all responses should be included in calculating the mean willingness-to-pay. Sample selection bias, due to the exclusion of invalid responses, may cause one or both of the following consequences. The empirical analysis of the valuation function used to test for theoretical validity may give inconsistent parameter estimates, and the estimated benefit measures and hence the aggregated values may also be biased.

\subsection{How informed the respondents were and what their attitude was toward the freshwater allocation issue}

The majority of respondents were well-informed about the ecological functioning of the Keurbooms Estuary and were disposed to favour allocations of freshwater to the estuary over allocations to the residents of Plettenberg Bay for consumption. More specifically, 48 per cent of the respondents were well-informed, 44 per cent were not clear and 8 per cent were poorly informed. Only 5,3 per cent of the respondents preferred allocations of freshwater to the residents of Plettenberg Bay, whereas 79,5 per cent preferred allocations to the estuary. Approximately 15,2 per cent of the respondents preferred the current allocation levels.

\subsection{Willingness-to-pay}

The statistics relating to the willingness to pay are shown in Table 3 below.

Table 3 Analysis of the willingness-to-pay statistics

\begin{tabular}{|l|c|c|c|c|c|c|c|c|}
\hline Variable & $\begin{array}{c}\text { Popu- } \\
\text { lation }\end{array}$ & $\begin{array}{c}\text { Mean } \\
\text { Rand }\end{array}$ & $\begin{array}{c}\text { Standard } \\
\text { deviation } \\
\text { Rand }\end{array}$ & $\begin{array}{c}\text { Min } \\
\text { Rand }\end{array}$ & $\begin{array}{c}\text { Median } \\
\text { Rand }\end{array}$ & $\begin{array}{c}\text { Max } \\
\text { Rand }\end{array}$ & $\begin{array}{c}\text { 95\% } \\
\text { Lo } \\
\text { Rand }\end{array}$ & $\begin{array}{c}\text { 95\% } \\
\text { Hi } \\
\text { Rand }\end{array}$ \\
\hline $\begin{array}{l}\text { Willing- } \\
\text { ness-to- } \\
\text { pay }\end{array}$ & 150 & 273,67 & 262,26 & 0,00 & 150,00 & 1500,00 & 231,35 & 315,98 \\
\hline
\end{tabular}

Analysis of the willingness-to-pay statistic shows that on average the respondents in this survey were willing to pay R273,67 each for sufficient freshwater inflows to keep the mouth of the Keurbooms open. 


\subsection{The willingness-to-pay function}

In order to better understand the determinants of the willingness-to-pay responses and test these against what would be expected, a willingness-to-pay function was estimated using Ordinary Least Squares. ${ }^{4}$

The function estimated took the following form:

$$
\mathrm{Y}=\sum_{\mathrm{i}=1}^{\mathrm{n}} \beta_{\mathrm{i}} \mathrm{X}_{\mathrm{i}}+\varepsilon
$$

where: $\quad \mathrm{Y}=$ WTP (dependent variable)

$\mathrm{X}=$ vector of $\mathrm{n}$ explanatory variables (independent variables)

$\beta=$ vector of $\mathrm{n}$ parameters

$\varepsilon=$ disturbance term

The explanatory variables selected for this purpose have already been identified above: annual levies, gender, distance from estuary, education level, worth-fixed property, worth-boats and vehicles and income. A statistical analysis of these variables is shown in Tables 4 and 5 below.

Table 4 An analysis of the explanatory variables in the WTP function

\begin{tabular}{|c|c|c|}
\hline Explanatory variables & Classes & $\%$ of sample in class \\
\hline \multirow[t]{8}{*}{ Annual levies } & $\mathrm{R}$ & $037.1 \%$ \\
\hline & $\begin{array}{lll}\mathrm{R} & 1-20\end{array}$ & $0.7 \%$ \\
\hline & $\mathrm{R} \quad 21-50$ & $2.0 \%$ \\
\hline & R $\quad 51-100$ & $4.0 \%$ \\
\hline & $\mathrm{R} 101-200$ & $13.2 \%$ \\
\hline & R $201-500$ & $37.1 \%$ \\
\hline & $\mathrm{R} \quad 501-1000$ & $6.0 \%$ \\
\hline & $>\mathrm{R} 1001$ & $0 \%$ \\
\hline \multirow[t]{2}{*}{ Gender } & Males & $73.5 \%$ \\
\hline & Females & $26.5 \%$ \\
\hline \multirow[t]{6}{*}{ Distance from estuary } & $0-1 \mathrm{~km}$ & $16.6 \%$ \\
\hline & $1-3 \mathrm{~km}$ & $27.2 \%$ \\
\hline & $3-5 \mathrm{k}$ & $27.8 \%$ \\
\hline & $5-10 \mathrm{~km}$ & $11.9 \%$ \\
\hline & $11-15 \mathrm{~km}$ & $3.3 \%$ \\
\hline & $<15 \mathrm{~km}$ & $13.2 \%$ \\
\hline
\end{tabular}




\section{Table 4 continued}

\begin{tabular}{|c|c|c|}
\hline Explanatory variables & Classes & \% of sample in class \\
\hline \multirow{5}{*}{$\begin{array}{l}\text { Education } \\
\text { respondents }\end{array}$} & Matric & $44.7 \%$ \\
\hline & Post matric & $3.3 \%$ \\
\hline & Diploma & $18.7 \%$ \\
\hline & Degree & $26.7 \%$ \\
\hline & Postgraduate degree & $6.7 \%$ \\
\hline \multirow[t]{7}{*}{ Worth - fixed property } & R 0 & $0 \%$ \\
\hline & R1 $000-$ R50 000 & $2.0 \%$ \\
\hline & R50 $001-\mathrm{R} 100000$ & $2.0 \%$ \\
\hline & R100 001 - R200 000 & $3.3 \%$ \\
\hline & R200 $001-$ R500 000 & $34.4 \%$ \\
\hline & R500 $001-\mathrm{R} 1000000$ & $30.5 \%$ \\
\hline & $>$ R1 000000 & $27.8 \%$ \\
\hline \multirow[t]{7}{*}{ Worth - boats vehicles } & R 0 & $0 \%$ \\
\hline & R1 $000-$ R 50000 & $18.5 \%$ \\
\hline & R50 001 - R100 000 & $45.0 \%$ \\
\hline & R100 $001-\mathrm{R} 200000$ & $24.5 \%$ \\
\hline & R200 $001-$ R500 000 & $9.9 \%$ \\
\hline & R500 $001-\mathrm{R} 1000000$ & $1.3 \%$ \\
\hline & $>$ R1 000000 & $0.7 \%$ \\
\hline \multirow[t]{4}{*}{ Income } & R $0-$ R 60000 & $4.6 \%$ \\
\hline & R60 001 - R120 000 & $37.1 \%$ \\
\hline & $\mathrm{R} 120001-\mathrm{R} 250000$ & $47.7 \%$ \\
\hline & $>$ R250001 & $10.6 \%$ \\
\hline
\end{tabular}

Table 5 Descriptive statistics

\begin{tabular}{|l|r|r|r|r|r||}
\hline Variable & \multicolumn{1}{|c|}{ Mean } & Std Dev. & \multicolumn{1}{c|}{ Min } & \multicolumn{1}{c|}{ Max } & Median \\
\hline Annual Levies & 198,11 & 207,90 & 0,00 & 750,0 & 150,00 \\
\hline Gender & - & - & - & - & - \\
\hline Distance & 5,36 & 5,43 & 0,50 & 17,50 & 4,00 \\
\hline Education & - & - & - & - & - \\
\hline Worth - fixed property & 773180 & 494020 & 25000 & 1500000 & 750000 \\
\hline Worth - boats/vehicles & 129800 & 161260 & 25000 & 1500000 & 750000 \\
\hline Income & 164110 & 86660 & 60000 & 375000 & 185000 \\
\hline
\end{tabular}

The majority of respondents (i.e. 63 per cent) paid annual levies, with most paying between R101 and R500, suggesting that most of the respondents interviewed made direct use of the recreational services provided by the estuary (for boating, fishing etc.). Only 13 per cent of the respondents interviewed had residences 
located more than fifteen kilometers from the estuary. About 55 per cent of the respondents had tertiary education - all of the respondents had obtained a matric certificate. The majority of the respondents (93 per cent) owned fixed property worth in excess of R200 000. About 45 per cent of the respondents owned boats and vehicles worth between R50 001 and R100 000. Only 4.6 per cent of the respondents interviewed earned less than R60 000 per annum. Almost half of the respondents (47.7 per cent) earned between R120 001 and R250 000 per annum.

The results of the estimation of the WTP function (Equation 2) are shown in Table 6.

Table 6 Estimation results of the WTP function $(n=150)$

\begin{tabular}{|l|c|c|c|c|}
\hline \multirow{2}{*}{ Explanatory variable } & \multicolumn{4}{|c|}{$\begin{array}{c}\text { Dependent Variable } \\
\text { Money Contribution (Rand) }\end{array}$} \\
& \multicolumn{4}{|c|}{$\mathbf{2}=\mathbf{0 , 3 4 4 1}$ f-stat $=$} \\
\hline & $\begin{array}{c}\text { Estimated } \\
\text { coefficient }\end{array}$ & Std error & t-statistic & P-value \\
\hline Annual levies & 43,5517 & 25,6030 & 1,70 & 0,09 \\
Gender & 25,1839 & 46,3417 & 0,54 & 0,59 \\
Distance & $-13,2906$ & 23,1979 & $-0,57$ & 0,57 \\
Education & $-7,8196$ & 39,5858 & $-0,20$ & 0,84 \\
Worth - fixed property & 7,1027 & 38,3607 & 0,19 & 0,85 \\
Worth - boats/vehicles & 74,9987 & 27,2785 & 2,75 & 0,01 \\
Income & 53,2494 & 41,6542 & 1,28 & 0,20 \\
\hline
\end{tabular}

The parameter estimates of several variables in the regression analysis were insignificant at 90 per cent (Table 6): gender, distance, education, worth - fixed property and income. When these insignificant predictors are eliminated and the function is re-estimated the results change to those shown in Table 7.

Table 7 Estimation of a revised willingness-to-pay function - including significant variables only $(n=150)$

\begin{tabular}{|c|c|c|c|c|}
\hline \multirow[t]{2}{*}{ Explanatory variable } & \multicolumn{4}{|c|}{$\begin{array}{l}\text { Dependent variable } \\
\text { Money contribution }\left(\text { Rand) } R^{2}=0,3213 \text { f-stat }=\right. \\
23,043\end{array}$} \\
\hline & $\begin{array}{l}\text { Estimated } \\
\text { coefficient }\end{array}$ & Std error & $\begin{array}{c}\mathbf{t}- \\
\text { statistic } \\
\end{array}$ & P-value \\
\hline Annu & 82.2038 & & 2,97 & 0,00 \\
\hline Worth - boats/vehicles & 107020 & 20,7103 & 5,17 & 0,00 \\
\hline
\end{tabular}


The results shown in Table 7 indicates that those respondents who pay higher annual levies and those respondents who own boats and vehicles of higher worth are more willing to pay money to conserve the Keurbooms Estuary. These parameter signs accord with a priori expectations.

\subsection{Two estimates of the value of freshwater inflows into the Keurbooms Estuary}

In order to calculate the value (per cubic metre) of freshwater flowing into the Keurbooms Estuary the total WTP amount was divided by the minimum amount of freshwater inflows needed to keep the estuary mouth open. The latter amount of water was estimated at $78540000 \mathrm{~m}^{3} / \mathrm{a}$ using expert opinion (Hosking et al., 2002). The total WTP was calculated in two ways: as the product of the mean WTP per user and the total number of users and as a product of the mean WTP and the estimated number of households. These products are shown in Table 8 below.

\section{Table 8 Average and aggregated benefit measures}

\begin{tabular}{|l|c|c|}
\hline Mean user WTP & Total number of users of estuary & Total WTP \\
\hline R273.67 & 13250 & R3 626 128 \\
\hline Estimated number of households* & R906 395 \\
\hline R273.67 & 3312 & \\
\hline
\end{tabular}

* Note: Assuming four-person households.

The recreational environment value of water per $\mathrm{m}^{3}$ was calculated as the total willingness-to-pay divided by the minimum required fresh water. Where the population is taken to be the users:

$\mathrm{P}_{\mathrm{w}}=\frac{R 3626128}{78540000 \mathrm{~m}^{3}}=\mathrm{R} 0,046 / \mathrm{m}^{3}$

Where the population is restricted to household heads:

$\mathrm{P}_{\mathrm{w}}=\frac{R 906395}{78540000 \mathrm{~m}^{3}}=\mathrm{R} 0,012 / \mathrm{m}^{3}$

These estimates exclude demand from non-current-users, e.g. people who we could not identify that had bequest, option and existence demand. 


\section{CONCLUSION}

This paper applies the contingent valuation method to value the freshwater inflow into the Keurbooms in terms of the services yielded to recreation users of the estuary. The value (excluding non-current-users) of this water was estimated by reference to both the total user population and the household heads. For the former case the estimate was $\mathrm{R} 0,046 / \mathrm{m}^{3}$ and for the latter R0,012/ $\mathrm{m}^{3}$. Estimation of a willingness-to-pay function show annual levies paid and investment in access to recreation services as the major factors determining the willingness-to-pay response. Unfortunately, the potential for error exists due to the smallness in sample size ( 5 per cent of the sample population). Given the small sample size and the hypothetical circumstances in which contingent valuation studies are made comparisons with other values of water should be made with caution.

The values of water estimated here are lower than the value of the water for farming in this area as calculated using the income capitalisation method, which is $12,5 \mathrm{c} / \mathrm{m}^{3}$ (Hosking et al., 2002). However, the values of freshwater inflow into estuaries can be expected to increase as estuary services are undermined at more and more locations in South Africa and demand for them increases.

We would encourage policy makers to endeavour to create an awareness and educate people, especially those who live in close proximity to estuaries, regarding the importance of estuaries as ecological and tourism hotspots. Furthermore, policy makers should be made aware that upstream water impacts, such as too high abstraction or insufficient dam water releases, constitute the source of a loss of value in the recreational services yielded by estuaries.

\section{ENDNOTES}

1 We would like to acknowledge the contributions of the users of the Keurbooms estuary who responded to this survey and to the enumerator, George Dimopoulos, who administered the final survey, VA Veck and MR Bill who commented on the questionnaire design, and Danie Venter who assisted with data entry and analysis, and anonymous referees for their valuable suggestions. Finally we would like to express our thanks to the Water Research Commission for funding this project and the Steering Committee members who have contributed to this work with comments, especially the Project Manager, Dr Gerhard Backeberg.

2 Other well-known resource valuation techniques, such as the travel cost method (TCM) and the hedonic pricing method (HPM), are much more difficult to target at specific negative ecological impacts such as discussed 
above. Travel cost method uses total expenditure to get to an area as its value basis and hedonic pricing method uses proximity as its value basis.

3 This is a biased estimate in that non-use values were not captured in this study. Envisaged non-use benefactors would include all those people who would be prepared to pay something to preserve the Keurbooms Estuary even though they do not intend to extract any direct benefit. This group would include conservation-minded people all over the world. Amongst those groups who were not captured in our CVM were option value users, people who would wish to pay to maintain the estuary for succeeding generations and those people who attach a high value to conservation.

4 It is important to note that if $\mathrm{R}^{2}$ values for valuation functions are less than 15 per cent the credibility of the values should be called into question (Mitchell \& Carson, 1989).

\section{REFERENCES}

1 AGUILAR, M. \& STERNER, G. (1995) "Willingness to pay for improved communal water services," Studies in Environmental Economics and Development, Environmental Economics United, Department of Economics, Göteborg University: Göteborg.

2 BENNETT, B.A. (1989) "A comparison of the fish communities in nearby permanently open, seasonally open and normally closed estuaries in the South-Western Cape, South Africa," South African Journal of Marine Science, 8: 43-55.

3 BLABER, S.J.M. \& WHITFIELD, A.K. (1976) "Large scale mortality of fish at St Lucia," South African Journal of Science, 73: 218.

4 CARSON, R.T. (1991) "Constructed markets," in: Braden, J.B., \& Kolstad, C.D. (eds.) Measuring the Demand for Environmental Quality, Elsevier Science Publishers, B.V.: North Holland.

5 CIRIACY-WANTRUP, S.V. (1952) Resource Conservation: Economics and Politics, University of California Press: Berkley.

6 CHOE, K., PARKE, W.R. \& WHITTINGTON, D. (1999) “A Monte Carlo comparison of OLS estimation errors and design efficiencies in a two-stage stratified random sampling procedure for a contingent valuation study," in: Bateman, I.J. \& Willis, K.G. (eds.) Valuing Environmental Preferences, Oxford University Press: New York: 280-301.

7 DAVIS, R. (1963) "Recreation planning as an economic problem," Natural Resources Journal, 3(2): 239-49.

8 DIXON, J.A. \& SHERMAN, P.B. (1990) Economics of Protected Areas, Island Press: Washington, D.C. 
9 GEORGIOU, S., WHITTINGTON, D., PEARCE, B. \& MORAN, D. (1997) Economic Values and the Environment in the Developing World, Edward Elgar: Cheltenham.

10 GRIFFIN, C.C., BRISCOE, J., SINGH, B., RAMASUBBAN, R. \& BHATIA, R. (1995) "Contingent valuation and actual behaviour: Predicting connections to new water systems in the State of Kerala, India," The World Bank Economic Review 9(3): 373-95.

11 HANEMANN, W.M. (1999) "Neo-classical economic theory and contingent valuation," in Bateman, I.J. \& Willis, K.G. (eds.) Valuing Environmental Preferences, New York: Oxford University Press: 42-96.

12 HANLEY, N. \& SPASH, C.L. (1993) Cost Benefit Analysis and the Environment, Edward Elgar Publishing: Vermont.

13 HOSKING, S.G., DU PREEZ, M., CAMPBELL, E.E., WOOLDRIDGE, T.H. \& DU PLESSIS, L.L. (2002) Evaluating the Environmental use of Water - Selected Case Studies in the Eastern and Southern Cape, Pretoria: Water Research Commission Report No. 1045/0/1.

14 HUIZINGA, P. \& SLINGER, J. (1996) "Physical dynamics of the Keurbooms-Bitou and Piesang estuaries," in: Plettenberg Bay Coastal Catchments Study, Phase 2, Environmental Worksession, DWAF.

15 MITCHELL, R.C. \& CARSON, R.T. (1989) Using Surveys to Value Public Goods: The Contingent Valuation Method, Resources of the Future: Washington DC.

16 REDDERING, J.S.V. (1988) "Prediction of the effects of reduced river discharge on the estuaries of the south-eastern Cape Province, South Africa," South African Journal of Science, 84: 726-30.

17 TIETENBERG, T.H. (2000) Environmental and natural resource economics, Addision-Wesley: New York.

18 TURNER, R.K., PEARCE, D. \& BATEMAN, I. (1993) Environmental Economics: an Elementary Introduction, Johns Hopkins University Press: Baltimore.

19 TURPIE, J. \& JOUBERT, A. (2000) The Tourism Value of Rivers in Kruger National Park and Impacts of a Change in River Quality, University of Cape Town: Cape Town, unpublished report.

20 VECK, V.A. \& BILL, M.R. (2000) Estimation of the Residential Price Elasticity of Demand for Water by Means of a Contingent Valuation Approach, Report to the Water Research Commission: Pretoria, No. 790/1/00.

21 WHITFIELD, A.K. (1989) "Ichthyoplankton interchange in the mouth region of a southern African estuary," Marine Ecology Progress Series, 54: 25-33.

22 WHITFIELD, A.K. \& KOK, H.M. (1992) "Recruitment of juvenile marine fishes into permanently open and seasonally open estuarine systems on the 
southern coast of South Africa," Ichthyological Bulletin of the J.L.B. Smith Institute of Ichthyology, 57: 39pp.

23 WHITTINGTON, D. (1996) "Administering contingent valuation surveys in developing countries", Environmental Economics Program for Southern and Eastern Asia Working Paper.

24 WHITTINGTON, D., BRISCOE, J., MU, X. \& BARRON, W. (1990) "Estimating the willingness to pay for water services in developing countries: A case study of the use of contingent valuation surveys in Southern Haiti," Economic Development and Cultural Change, 38(2): 293311.

25 WOOLDRIDGE, T.H. (2000) Ecology of the Keurbooms and Bitou Estuaries. Unpublished report, Department of Zoology, University of Port Elizabeth: Port Elizabeth. 